\title{
Sustainability Reporting and Accounting in Measuring the Costs of Flared Dry Gas Industry
}

\author{
${ }^{1}$ Sandoval Ross and ${ }^{2}$ Ed. Thompson \\ ${ }^{1}$ United International Business Schools, Rambla de Catalunya 2-4, Barcelona, Spain. \\ ${ }^{1}$ rosssandoval@barcelona.uibs.org
}

\author{
Article Info \\ Journal of Journal of Enterprise and Business Intelligence (http://anapub.co.ke/journals/jebi/jebi.html) \\ Doi: https://doi.org/10.53759/5181/JEBI202101008 \\ Received 22 September 2020; Revised form 15 October 2020; Accepted 25 December 2020. \\ Available online 05 April 2021. \\ (2021 Published by AnaPub Publications.
}

\begin{abstract}
The sector oil and gas are very importance in the Iraqi economy, and natural gas cause less pollution to the environment. Due to the conditions that the country went through, the existing infrastructure is unable to process the quantities of natural gas associated with the extraction of crude oil, therefore it is treated by burning. This has harmful effects on the environment and society. In addition, the expenditure on treating is very large and the country suffer a large loss of revenue in the atmosphere. Therefore, the responsible authorities should decide to limit these burning processes through the information on economy, environment and society that sustainability accounting provides. Also, the company being studied shows that there are a lot of costs incurred by burning dry gas for two reasons: compressors stop working and network pressure. This is a waste of the natural resource and of large sums that could have been revenues for the country. Although there are also disadvantages on the environment and society, the company's expenditure on the environment and society is small compared to the costs spent on producing dry gas. This does not support sustainable development, and the study concludes with some conclusions and recommendations.
\end{abstract}

Keywords - Sustainability Accounting; Sustainable Development; Dry Gas.

\section{INTRODUCTION}

It has become clear that industrial companies in general oil companies significantly deplete and waste natural resources and cause environmental pollution. Today, sustainable development is one of the most important aims of countries to reduce this waste and depletion and helps to save the environment. Therefore, these companies have to take responsibility to prevent this waste and depletion and improve their effects on the environment, society and costs. Today, natural gas is a very important energy sources due to its growing demand, industry development and calorific value. In accounting, sustainability is one of the most important modern advances to support sustainable development, because accounting is an information system that measures and discloses the company's economy, environment and society because it is the official information source in the company. Therefore, accountability in general and sustainable development accountability in particular must play a key role in explaining the relationship between burning natural gas and sustainable development. The identification, measurement and analysis of the costs and losses of the burning gas could improve the company's economy, environment and society as the interest in the costs, revenues and benefits become very important because of their link with the individual's well-being, standard of living and future.

\section{Problem of the Research}

\section{METHOD OF RESEARCH}

The Significance of This Research because it:

- Explains the importance of natural gas in the economy, on which the country relies on in the operation of many companies to meet local needs, and what remains is exported.

- Presents a vision that shows the dry gas burning increases with the increase of production, incurring financial losses and waste in addition to harming the environment.

- Refers to the role that sustainability accounting plays in supporting sustainable development by measuring the costs of burning dry gas to reach economic, environmental and social integration. 
- Provides important information to the company on the costs of combustion of dry gas helping the administration in rationalizing the decisions related to the burning gas.

\section{Research Goals}

In light of the research problem and the importance of the research, the research aims to:

- Learn about the concept of sustainability accounting and its importance, as well as sustainable development.

- Explain the concept and importance of natural gas and the costs of burning it.

- State the financial incurring costs by gas burning, and the environmental and social consequences.

Research hypothesis

The hypotheses of the Research are the following:

There is a relationship between sustainability accounting and the dry gas burning with the following subhypothesis:

- Sustainability accounting can measure the costs of the burned dry gas.

- Sustainability accounting can measure the environmental costs to protect the environment

- Sustainability accounting can measure the social costs spent to satisfy the community.

- Sustainability accounting has an effective role to support sustainable development

\section{Research methods}

The two researchers use the descriptive and analytical approach in the theoretical part, and the literature is collected through Arab and foreign references, relevant previous research and studies, and the information is obtained from internet. As for the practical part the information is obtained through:

- Field visit to the companies under investigation (the South Gas Company and Al-Basra Gas Company) to conduct interviews with experts and accountant officials, the technical body and the commercial body.

- Collecting the available data on the quantities of burnt gas as well as the related costs.

Sample and limitations

- Spatial Limitation is South Gas Company and Al- Basra Gas Company

- Time limitations the two financial period are 2018-2019.

\section{THEORETICAL PART}

\section{Sustainability accounting}

Organizations and governments increasingly demand paying attention to energy, rationalizing the use of natural resources, preserving the environment from the changes that occur due to the pollutants from the industrial companies, and aspiring the social welfare. Thus, some countries have legislated laws and rules to comply with the requirements of sustainable development, and now companies' commitment to government legislation and laws is evaluated. These evaluations significantly affect the reputation of the company [1]. This has led to change traditional accounting into sustainability accounting so it combines data form inside and outside the company to benefit the company to achieve its economic goals with the needed data and preserve the environment and society. It also enables the company to measure its results and disclose them to the beneficiaries. Furthermore, it helps the company to measure its contribution to sustainable development by integrating economic, environmental and social aspects [3]. Studies linking accounting to the concept of sustainability appeared in the early 1990s and found constant interest in the academic and professional accounting literature. Then the guidelines for sustainability disclosure at the sustainable development summit were shown in August 2002, integrating different approaches into the sustainability accounting framework. The result was a model for comprehensive disclosure that companies adhere to for assessing the extent of their contribution to sustainability. Gray points out that all things related to sustainability remains the subject of great controversy, as sustainability accounting is either considered a resonant word and will disappear after a while, or it is a guided path by the management that recognizes the importance of managerial decision-making. Gray also states that sustainability accounting is a set of tools that helps managers to deal with various decisions [6]. Lamberton defines sustainability accounting as a triple bottom line (TBL), which aims to report the economic, social and environmental impacts of an organization [11]. 


\section{Accounting measurement}

The most commonly used measurements are based on historical cost and fair value. Generally, historical costs require accounting principles that companies use to calculate and report many assets and liabilities on the basis of the purchase price. The fair value is the price that would be received to sell an asset or paid to transfer a liability in an orderly transaction between the market participants at the measurement date, i.e. it is a market-based measure [10].

\section{Sustainable development}

Du Pisani argues that with the advancement of science and technology and the growth of the global economy, the concept of "development" has received a great interest. It has also been defined as an evolutionary process in which human capacities have increased in terms of starting new structures, dealing with problems, adapting to continuous change and meaningful and creative seeking new goals [5]. Mallette defines sustainable development as the ability of the environment to work indefinitely using clean technologies alongside renewable resources. This is to achieve sustainability in both consumption and production. In this way, the present time needs of people are fulfilled without endangering the well-being of future generations [12].

The interrelationship between sustainability accounting and sustainable development

Sustainability accounting is an important tool that can be used to help companies become more sustainable. It explains the important role of financial information in expressing sustainability, and how traditional financial accounting can evolve to integrate the environmental and social impacts of the company's activities.

\section{Financial Accounting}

Uno believes that assets may be non-financial, which could also include non-productive or intangible natural assets related to human capital. Also, the liabilities may be related to social or environmental matters. However, there are conflicting points, especially in the case of assessing the economic use of the environment. Although experts roughly agree on the necessity of measuring the environmental damage and inferring it from positive achievement, they differ in the methodology of conducting the accounting treatments [15].

\section{Environmental Accounting}

Schaltegger \& Burritt clarify that the work of management through environmental accounting distinguishes different decision situations and encourages management to identify their information needs and choose appropriate tools. Here, it is necessary to distinguish between two directions for the development of an accounting system for the sustainability of development:

- The top-down approach to develop sustainability accounting begins with the broadest definition of sustainable development and corporate sustainability. From this approach, the benchmarking approach is derived.

- The stakeholder approach is conducted through stakeholder engagement processes. Its basic logic is that if the management wishes to make sustainability a real phenomenon, stakeholder participation is a prerequisite for the business strategy to develop an effective sustainability accounting system. Also, it is more closely related to reporting requirements and social satisfaction, which facilitate making sustainability accounting that agree with the strategic goals and competitive strategy of the company [13].

\section{Social responsibility accounting}

Social responsibility accounting includes many elements at the same time. The first is a fairly straightforward manifestation of the company's efforts to clarify, explain and justify the legitimacy of its activities. The second is a desirable ethical component that works well, and the third is an available mechanism to address sustainability. It illustrates the social and environmental impacts arising from traditional accounting practices. Also, it provides information to stakeholders about the extent of the company's commitment to its responsibilities towards society [7].

\section{Natural gas}

Natural gas was discovered and identified in America in 1626 [16]. In Iraq, gas industries at the commercial level dates back to 1927, although Iraq has a large wealth of free natural gas, natural gas emitted from crude oil production and high probable and proven reserves [8]. Natural gas is known as the source of fossil energy that is formed deep under the earth's surface and natural gas contains many different compounds. The largest component is methane, small amounts of natural gas liquids (NGL, which are also hydrocarbon gas liquids), and gases such as carbon dioxide and water vapor [9]. 
Natural gas has several forms that differ according to the way it is formed:

- Accompanied gas: this gas accompanies oil, either in a dissolved form or as a cover of free gas, and drilling companies ignite or vent this gas routinely for safety reasons or as an unwanted by-product of oil production [2].

- 2-Free gas: hydrocarbon compounds is found in natural gas fields, in which methane constitute high proportions compared to non-hydrocarbon materials that are low in this type of natural gas. The nonaccompanied gas can be produced at high pressure and requires minimal treatment before it is transported to pipelines [14].

Natural gas production costs

The natural gas production cost includes all costs the companies spend in the oil and gas sectors, from the stage of research and exploration until the stage of marketing or exporting gas:

- Acquisition costs are the costs incurred by possessing a property, that is, the costs of obtaining the rights to explore, drill and produce oil and natural gas.

- Exploration costs are costs, such as the costs of determining exploration drilling areas and the costs of examining samples.

- Development costs are the costs to prepare proven reserves for production, that is, costs incurred by reaching proven reserves and providing facilities for the extraction, processing, collecting and storing gas.

- Production costs are the costs incurred by raising oil and gas to the surface, and in collecting, processing and storing it.

The relationship between sustainability accounting and gas industry

Gases emitted from burning natural gas negatively affect the environment and the climate and cause global warming. This is a challenge to sustainable development. To reduce the degree and speed of warming, the method of production, use of gas and the regulation of economic and social life should be reviewed. The existing energy sectors face great challenges that are difficult to overcome despite the technological development. Emissions of greenhouse gases in the atmosphere, including carbon dioxide (CO2) and high levels of NOx, and SOx are caused by the use of natural gas in the production of electricity $66 \%$ and transportation sectors $22 \%$. Krishna et al point out that energy resources should continue to be explored and produced. However, this has to be done safely, environmentally sound and in a socially responsible manner. This requires protecting the environment, respecting the rights of others, as well as protecting the health, safety and security of workers and society. Also, Bebbington [4] clarifies the dimensions of sustainable development in the gas industry: the economic, the environmental, and the social, as shown in the following table 1:

Table 1: Dimensions of sustainable development in gas industry

\begin{tabular}{|c|l|}
\hline \multicolumn{2}{|c|}{ Sustainable dimensions } \\
\hline Economy & -Working capacity \\
& -Developing new techniques \\
& -Activating trade \\
& \\
\hline Environment & -Understating and identifying environmental impacts \\
& -Administering environmental impacts \\
& - Reducing energy use \\
& -Processing the waste \\
\hline Society & -Circumstance and safety of workers \\
& -Supporting skills and training \\
& -Connecting with the society \\
\hline
\end{tabular}


The study samples

\section{THE PRACTICAL SIDE}

South Gas Company: The South Gas Company is a production company working on the accompanied natural gas processing, which includes Al-Rumaila, West Qurna and Zubair complexes. It was established in 1998 and contains 18 compressor stations with a total capacity of 29.7 million $\mathrm{m}^{3}$ per day. Also, it works to support the economy through the oil and gas sectors. It processes natural gas to produce dry gas and gas liquids to meet the local need and exporting the surplus producing condensate for export. Al- Basra Gas Company: Al-Basrah Gas Company was established in May 2013 as a mixed sector company. It consists of the Southern Gas Company, the main shareholder $(51 \%)$, and Shell and Mitsubishi $(49 \%)$ to process natural gas, reduce the burned quantities, increase production, and contribute to sustainable development. It is the only producer of liquid gas and assists in the production of dry gas for gas power plants and for exports of condensate. This is explained in the table 2 the researcher prepared:

Table 2: Costs of dry gas production for Al-Basra Gas Company for the year 2018/2019, amounts in dollars

\begin{tabular}{|c|c|c|c|c|}
\hline \multicolumn{5}{|c|}{ A list of the total costs of producing dry gas, and the cost per unit } \\
\hline & \multicolumn{2}{|c|}{2018} & \multicolumn{2}{|c|}{2019} \\
\hline Production costs & & $\$ 265200000$ & & $\$ 279000000$ \\
\hline \multicolumn{5}{|l|}{ Costs of the company departments } \\
\hline Financial and accounting & $\$ 10400000$ & & $\$ 19000000$ & \\
\hline Legal affairs and general manager's office & $\$ 80000$ & & $\$ 300000$ & \\
\hline Human resources, structure and land rents & $\$ 12900000$ & & $\$ 17800000$ & \\
\hline Security and protection & $\$ 9900000$ & & $\$ 11000000$ & \\
\hline $\begin{array}{c}\text { Material, Transport and Transportation } \\
\text { Authority }\end{array}$ & $\$ 11600000$ & & $\$ 13000000$ & \\
\hline The total costs of the company's departments & & $\$ 44800000$ & & $\$ 61100000$ \\
\hline \multicolumn{5}{|l|}{ Social costs } \\
\hline \multicolumn{5}{|l|}{ Taking care of the workers } \\
\hline Costs of occupational safety and health & $\$ 3700000$ & & $\$ 4500000$ & \\
\hline Development and training & $\$ 300000$ & & $\$ 400000$ & \\
\hline \multicolumn{5}{|l|}{$\begin{array}{l}\text { Taking care of the community outside the } \\
\text { company }\end{array}$} \\
\hline Social performance & $\$ 220000$ & & $\$ 1000000$ & \\
\hline Total social costs & & $\$ 4220000$ & & $\$ 5900000$ \\
\hline Environmental costs & & $\$ 420000$ & & $\$ 500000$ \\
\hline Total production costs & & $\$ 314640000$ & & $\$ 346500000$ \\
\hline The quantity produced reagent & & 214983.7 & & 237371 \\
\hline The cost of one reagent & & $\$ 1463.6$ & & $\$ 1459.7$ \\
\hline
\end{tabular}

Table. 2 shows the costs of producing dry gas in 2018-2019:

- $\quad$ Production costs for 2018 and 2019 are 265,200,000 and 279,000,000 dollars, respectively.

- The total costs of the company's divisions for production of 2018 are 44800000 dollars and for 2019 are 61100000 dollars.

- It is also noticed that the total social costs represented by the cost of caring for workers and the cost of caring for society outside the company for 2018 and 2019 are 4220000 dollars and 5900000 dollars, respectively. However, the total environmental costs for the two years are 420,000,500,000 dollars, respectively.

- As the table shows, the total costs of production are 314640000 dollars to produce (214983.7) MMSCF. When these costs are divided by the quantity of production, the cost of producing one MMSCF is 1463.6 dollars. In 2018, the total production cost is (346500000) dollars to produce (237371) MMscf. By dividing these costs by the quantity of production, the cost of producing one MMSCF is (1459.7) dollars in 2019. 
According the above discussion, the rates have been calculated showing the relationship between costs as follows:

- First: The ratio of the index of the relationship between the items of social costs with the total social costs.

- Second: the items of social costs with the total costs of production.

- Third: environmental costs with the total costs of production.

- Fourth: The total social and environmental costs with the total costs of production.

According to the rules mentioned above, table no. 3 shows index of cost ratios based on the company's data:

Table 3: Indexes of rates of costs for $2018 / 2019$

\begin{tabular}{|c|c|c|c|}
\hline \multicolumn{2}{|r|}{ Cost items } & \multirow{2}{*}{$\begin{array}{l}\mathbf{2 0 1 8} \\
\text { Ratio }\end{array}$} & \multirow{2}{*}{$\begin{array}{l}2019 \\
\text { Ratio }\end{array}$} \\
\hline & & & \\
\hline \multirow[t]{3}{*}{ Total social costs } & Occupational and health safety costs & $\% 87.67$ & $\% 76.27$ \\
\hline & Training and development costs & $\% 7.10$ & $\% 6.77$ \\
\hline & Social performance costs & $\% 5.213$ & $\% 16.949$ \\
\hline \multirow{6}{*}{$\begin{array}{l}\text { Total production } \\
\text { costs }\end{array}$} & Occupational and health safety costs & $\% 1.175$ & $\% 1.299$ \\
\hline & Training and development costs & $\% 0.095$ & $\% 0.115$ \\
\hline & Social performance costs & $\% 0.07$ & $\% 0.289$ \\
\hline & Total social performance costs & $\% 1.341$ & $\% 1.703$ \\
\hline & Total environment costs & $\% 0.133$ & $\% 0.144$ \\
\hline & Total social and environment costs & $\% 1.474$ & $\% 1.857$ \\
\hline
\end{tabular}

Table 3 shows the indicators of the relationship of cost ratios as follows:

- The indicators of the ratios between the items of social costs and total social costs 2018 and 2019 are $87.67 \%$, $7.10 \%, 5.213 \%$ and $76.27 \%, 6.77 \%, 16.949 \%$, respectively. This means there is an increase in the health and occupational safety costs according to the total social costs with a decrease in the training and development costs and the costs of performance of the society according to the total social costs.

- It also shows the ratios of social cost to the total costs of production which is the lowest ratios of social cost items in $2018(1.175 \%, 0.095 \%, 0.07 \%)$, and in $2019(1.299 \%, 0.115 \%, 0.289 \%)$. The sum of these ratios represents the social costs the social services, which constitute only a (1,341\%) in 2018 and (1.703\%) in 2019 of the total costs of production.

- In 2018, the percentage of environmental costs is $0.133 \%$ and in 2019 it is $0.144 \%$ ) of the total costs of production.

- It also shows that the total social and environmental costs constitute $1.474 \%$ for the year 2018 , and $(1.847 \%)$ for the year 2019 of the total costs of production. This means that the weakly contribute to the social field and environmental protection as they are two significant dimensions of sustainable development.

Table 4: The costs of burning dry gas for the year 2018/2019

\begin{tabular}{|c|c|c|c|c|c|}
\hline \multicolumn{6}{|c|}{ Costs of dry burning gas for Al-Basra Gas Company for 2018} \\
\hline \multicolumn{2}{|c|}{ Quantity in MMscf } & $\begin{array}{l}\text { The cost of } \\
\text { one MMSCF }\end{array}$ & Cost in dollar & $\begin{array}{l}\text { exchange } \\
\text { rate }\end{array}$ & Costs in Iraq dinar \\
\hline Burning dry gas due to pistons & 4963 & $\$ 731.8$ & $\$ 3631923.4$ & 1200 & $4,358,308,080$ \\
\hline $\begin{array}{l}\text { Dry gas burning due to network } \\
\text { pressure }\end{array}$ & 6130 & $\$ 1463.6$ & $\$ 8971868$ & 1200 & $10,766,241,600$ \\
\hline Total & 11093 & & $\$ 12603791.4$ & 1200 & $15,124,549,680$ \\
\hline \multicolumn{6}{|c|}{ Costs of dry burning gas for Al-Basra Gas Company for 2019} \\
\hline Burning dry gas due to pistons & 2524 & $\$ 729.85$ & $\$ 1842141.4$ & 1200 & $2,210,569,680$ \\
\hline $\begin{array}{l}\text { Dry gas burning due to network } \\
\text { pressure }\end{array}$ & 12248 & $\$ 1459.7$ & $\$ 17878405.6$ & 1200 & $21,454,086,720$ \\
\hline Total & 14772 & & $\$ 19720547$ & 1200 & $23,664,656,400$ \\
\hline
\end{tabular}


Table 4 shows the costs of burning dry gas in 2018 and 2019 for two reasons, the first is that the compressors stop working, and the second type that causes burning is the network pressure if the quantity is. Therefore, the amount of gas burned in 2018 is 11093 MMscf, and the total cost is 12603791.4 dollars, and the corresponding amount is (15124549680) Iraqi dinars. Also, the amount of dry gas burned is 14772 MMSCF in 2019, and the cost of dry gas burned is 19720547 dollars, that is, 23,664,656,400 Iraqi dinars. This indicates a waste of natural resources and a great environmental and social damage.

Table 5: The lost profits by burning dry gas in 2018 and 2019

\begin{tabular}{|c|c|c|c|c|}
\hline \multicolumn{5}{|c|}{ Lost profits from burning produced gas in 2018} \\
\hline Quantity in MMscf & $\begin{array}{l}\text { Price of a } \\
\text { MMscf }\end{array}$ & Sum in Dollar & Exchange rate & Cost in Iraqi Dinar \\
\hline 11093 & 3679.8 & $\$ 40820021.4$ & 1200 & $48,984,025,680$ \\
\hline \multicolumn{2}{|c|}{$\begin{array}{l}\text { Dry gas burning cost is deducted (total } \\
\text { production) }\end{array}$} & $\$ 16235714.8$ & 1200 & $19,482,857,760$ \\
\hline \multicolumn{2}{|c|}{ Lost profit } & $\$ 24584306.6$ & 1200 & $29,501,167,920$ \\
\hline \multicolumn{5}{|c|}{ Lost profits from burning produced gas in 2019} \\
\hline Quantity in MMscf & Price of a MMscf & Sum in Dollar & Exchange rate & Cost in Iraqi Dinar \\
\hline 14772 & 4100 & $\$ 60565200$ & & $72,678,240,000$ \\
\hline \multicolumn{2}{|c|}{$\begin{array}{l}\text { Dry gas burning cost is deducted (total } \\
\text { production) }\end{array}$} & $\$ 21562688.4$ & 1200 & $25,875,226,080$ \\
\hline \multicolumn{2}{|c|}{ Lost profit } & $\$ 39002511.6$ & 1200 & $46,803,013,920$ \\
\hline
\end{tabular}

The table 5 shows that the costs of burning dry gas in 2018 is $16235714.8 \$$. This is when compressors do not stop, the burning dry gas is a fully produced dry gas which equals 19,482,857,760 Iraqi dinars. Thus, the lost profit is the difference between the cost of one MMSCF and the selling price of one MMSCF multiplied by the amount of dry gas burned (11093). It results in 24584306.6\$, which are 29,501,167,920 Iraqi dinars. Thus, according to table (5), the difference between the amount of dry gas burned at the selling price of 48,984,025,680 Iraqi dinars and the cost of burning dry gas with its total production is $(19,482,857,760)$ Iraqi dinars. In 2019 , the dry gas burning cost can reach 21562688.4 dollars. Thus, when the compressors do not stop, the burning dry gas is fully produced dry gas. It is worth 25875226080 Iraqi dinars. Using the formula of utilized to count 2018 lost profit, the 2019 lost profit is 14772. This results in 39002511.6 dollars which is 46803013920 Iraqi dinars and the lost profit as a result of burning dry gas. Thus, the difference between the amount of dry gas burned at the selling price of 72678240000 Iraqi dinars and the cost of burning dry gas in the total production can be (25875226080) Iraqi dinars .It is clear from the above that the dry gas is burned process for two reasons: compressors stop: the company must study the reasons for stopping the compressors and solve this issue. If the compressors stop working due to power failure, it is necessary to use gas turbines to provide the necessary electricity to operate the compressors. However, if breakings and maintenance stop the compressors, the company can rent or buy compressors.

Table 6: Rent or buy compressors

\begin{tabular}{||c|c|c|c|c|c||}
\hline \multicolumn{7}{|c|}{ Renting gas compressor } \\
\hline \hline Yearly cost in dinar & Exchange rate & Cost per year\$ & $\begin{array}{c}\text { Cost per } \\
\text { month\$ }\end{array}$ & $\begin{array}{c}\text { Cost per } \\
\text { dya } \$\end{array}$ & $\begin{array}{c}\text { Cost per } \\
\text { hous } \$\end{array}$ \\
\hline \hline $3,732,480,000$ & 1200 & 3110400 & $\$ 259200$ & $\$ 8640$ & $\$ 360$ \\
\hline \hline \multicolumn{7}{|c|}{ Buying gas compressor } & Production age & Price $\$$ \\
\hline \hline Yearly cost in Iraqi dinar & Exchange rate & Yearly cost $\$$ & & $10,000,000$ \\
\hline
\end{tabular}


In Table 6, the cost of renting the compressor per hour is 360 dollars, and its cost per day is 8640 dollars. Therefore, its monthly cost is 259200dollars. Therefore, the annual cost of leasing is 3110400 dollars, which is exchanged for 3,732,480,000 Iraqi dinars.

Network pressure: It is one of the important reasons for burning dry gas. This problem can be solved through dialogue and understanding between the Ministry of Oil, the Ministry of Electricity and the Ministry of Industry and Minerals to address this issue and support of the national economy .Base on the previous explanation, the average burned of dry gas produced by Al-Basra Gas Company is only about 35 MMSCF per day for the two years. Also, natural crude gas burned in Iraq per day is 1740 MMSCF helping to produce 1050 MMSCF of gas. These data show the role of sustainability accounting in supporting sustainable development as table 7 shows. The total production costs, social and environmental costs, and the cost of one MMscf.

Table 7: Total production costs, MMSCF cost, and social and environmental costs in 2018 and2019

\begin{tabular}{|c|c|c|}
\hline Costs & 2018 & 2019 \\
\hline Total production cost & $\$ 314640000$ & $\$ 346500000$ \\
\hline Cost of producing one MMscf & $\$ 1463.6$ & $\$ 1459.7$ \\
\hline Social cost & $\$ 4220000$ & $\$ 5900000$ \\
\hline Environment cost & $\$ 420000$ & $\$ 500000$ \\
\hline
\end{tabular}

Table 7 shows the total costs of producing dry gas and the cost of one MMSCF during the study period and in the sample companies:

- The lowest producing dry gas cost is in 2018 about 314640000 dollars, and the highest is in 2019 which could be (346500000) dollars.

- In terms of producing one MMSCF it is evident, the lowest cost is in 2019 that is 1459.7 dollars while the highest is in 2018 is about 1463.6 dollars.

Furthermore, the lowest contribution of the study sample company to social costs is 4,220,000 in 2018 dollars, while the highest is 5900,000 dollars 2019. In environmental costs, the lowest contribution is in 2018, which is 420,000 dollars, while the highest is in 2019, which is 500,000 dollars.

Table 8: Costs and lost profits of burning dry gas in 2018 and 2019

\begin{tabular}{|c|c|c|}
\hline Costs and lost profits & 2018 & 2019 \\
\hline Costs of burning dry gas & $\$ 12603791.4$ & $\$ 19720547$ \\
\hline Lost profits of burning dry gas & $\$ 24584306.6$ & $\$ 39002511.6$ \\
\hline
\end{tabular}

From the table 8, it appears that:

*The lowest cost of burning dry gas, which is \$ 12603791.4 is in 2018. In contrast, it is the highest in 2019 (\$ 19720547).

*Furthermore, 2018 has the lowest lost profit (\$ 24584306.6), while 2019 has the highest (\$ 39002511.6).

Accordingly, the sustainability accounting has contributed to measure the cost of burning dry gas indicating the quantities of dry gas burned with the accompanied waste and depletion of one of the most important natural resources. As a result, Iraq incurred great losses in three items. First, in burning gas, an important resource of natural resources is lost. Secondly, the cost of producing dry gas is an additional loss that will be borne by the national economy. The third is the cost of purchasing foreign dry gas to meet the need for operating electric power plants. Therefore, in a quantitative manner, sustainability accounting has identified and translated waste, depletion, weaknesses and inadequate use in the process of producing this natural resource. This diagnostic process is in itself an effective support for leveraged development. This confirms the second main hypothesis which entails that sustainability accounting plays a key role in supporting sustainable development.

\section{V.CONCLUSIONS}

Many studies are now interested in the broad theories and academy of accounting for sustainability and sustainable development. Sustainability accounting shares economic, environmental and social dimensions with sustainable development. Sustainability accounting, an information system, contributes to the quantitative disclosure of 
economic, environmental and social performance. It also helps companies' management take rational decisions related to the gas industry and shows the extent of commitment and contribution of the investigated companies in environmental and social laws and legislation. The study shows that sustainable development aims to achieve justice and equality between generations and the necessity to consume as little as possible of permeable natural resources, as its consumption in an unimportant manner will lead to serious damage to the environment, society and economy .The study also explains the causes of dry gas burning the first of which is the stoppage of compressors due to holidays. The second is network pressure. The study also shows the quantities and costs of dry gas burning operations. The study reveals the ratios of total social costs to the total production costs, which rise up to $1.703 \%$ and $1.341 \%$ in 2019 and 2018 respectively. This indicates its weak contribution to social performance and the consequent damages caused by these of burning operations. The study also reveals that the ratios of environmental costs to total production costs in 2019 and 2018 are $(0.144 \%$ and $0.133 \%)$ respectively. This means the company is poorly contributing to the reduction of the environment pollution. This contribution is less than $1 \%$. This could be because of the lack of commitment of the studied companies to environment preservation legislation. The most important solutions to treat burning natural gas is comparing renting (\$3110400) and buying $(\$ 1,000,000)$ a compressor for one year of its productive life. The comparison shows that buying is better. Burning processed gas or crude gas or not treating makes a heavy burden to national economy and causes financial losses that could have contributed to enhancing the finance of the country.

\section{References}

[1]. H. Zhu, J. Gao, D. Li and D. Tang, "A Web-based product service system for aerospace maintenance repair and overhaul services", Comput. Ind., vol. 63, no. 4, pp. 338-348, May 2012.

[2]. W. Wang, F. Zhou, W. Li and J. Budd, "Designing the product-service system for autonomous vehicles", IT Prof., vol. 20, no. 6, pp. 62-69, Nov./Dec. 2018.

[3]. K. Hobson, N. Lynch, D. Lilley and G. Smalley, "Systems of practice and the circular economy: Transforming mobile phone product service systems", Environ. Innov. Societal Transitions, vol. 26, pp. 147-157, Mar. 2018.

[4]. W. Cao and P. Jiang, "Modelling on service capability maturity and resource configuration for public warehouse product service systems", Int. J. Prod. Res., vol. 51, no. 6, pp. 1898-1921, Mar. 2013.

[5]. Zhang, P. Jiang, J. Li, J. Hui and B. Zhu, "A distributed configuration scheme for warehouse product service system", Adv. Mech. Eng., vol. 9, no. 5, May 2017.

[6]. O. K. Mont, "Clarifying the concept of product-service system", J. Cleaner Prod., vol. 10, no. 3, pp. 237-245, Jun. 2002.

[7]. R. J. Hernandez-Pardo, T. Bhamra and R. Bhamra, "Exploring SME perceptions of sustainable product service systems", IEEE Trans. Eng. Manage., vol. 60, no. 3, pp. 483-495, Aug. 2013.

[8]. E. Maleki, F. Belkadi, N. Boli, B. J. van der Zwaag, K. Alexopoulos, S. Koukas, et al., "Ontology-based framework enabling smart product-service systems: Application of sensing systems for machine health monitoring", IEEE Internet Things J., vol. 5, no. 6, pp. 4496-4505, Dec. 2018.

[9]. Li, Y. Ji, L. Chen and R. J. Jiao, "Bi-level coordinated configuration optimization for product-service system modular design", IEEE Trans. Syst. Man Cybern. Syst., vol. 47, no. 3, pp. 537-554, Mar. 2017.

[10]. T. I. Katsaounis and A. M. Dean, "A survey and evaluation of methods for determination of combinatorial equivalence of factorial designs", J. Stat. Planning Inference, vol. 138, no. 1, pp. 245-258, Jan. 2008.

[11]. Wang, C. Zong, X. Guan, R. Xing and R. Xing, "Method of determining weights of subjective evaluation indexes for car handling and stability based on fuzzy analytic hierarchy process", J. Mech. Eng., vol. 47, no. 24, pp. 83-90, Dec. 2011.

[12]. K. Dmowski, "Side data analysis of deep level transient spectroscopy spectra for a multipoint correlation method with binomial weighting coefficients", Solid-State Electron., vol. 38, no. 5, pp. 1051-1057, May 1995.

[13]. Y. Ju and A. Wang, "Emergency alternative evaluation under group decision makers: A method of incorporating DS/AHP with extended TOPSIS", Expert Syst. Appl., vol. 39, no. 1, pp. 1315-1323, Jan. 2012.

[14]. Y. F. Yam and T. W. S. Chow, "Determining initial weights of feedforward neural networks based on least squares method", Neural Process. Lett., vol. 2, no. 2, pp. 13-17, Mar. 1995.

[15]. J. Chen and J. F. Bai, "Weight determination method based on principal component analysis coking", Adv. Mater. Res., vol. 712, pp. 2469-2473, Jun. 2013.

[16]. G. Huang and M. Wang, "Weight assignment research of improved entropy method in effectiveness evaluation", Comput. Eng. Appl., vol. 48, no. 28, pp. 245-248, 2012. 